\title{
Violence Against Women in Albanian Society
}

\author{
Arsen KIlogjri \\ PhD Candidate Clinical for Psychology, Tirana European University
}

\begin{abstract}
Violence against women is a phenomenon that in recent years a growing worldwide sensitive topic. What happens in the Albanian society is that battered women do not find support either in state institutions which are responsible for the protection of women's lives nor in social circles as the family which should show care for them on a good line. Lack of support for abused women do not report cases of violence, as it has resulted in interviews in our study. Recent years have increased efforts to mitigate and prevent this phenomenon yet statistics show shqtësuese society figures.
\end{abstract}

Keywords: violence against women, reporting, support networks, Culture

\section{Introduction}

Domestic violence occurs in many human societies, regardless of the level of economic and social development of them. It is a global phenomenon and affects all layers of the population of young and old, educated or illiterate, married or single, affecting every nationality, class, race or ethnic group. It includes violations of civil rights, cultural, economic, political and social human rights. Alarming data from around the world about the extent of domestic violence confirm the fact that domestic violence is an international problem. Fourth Conference of the United Nations in Beijing (1995) stated that violence against women constitutes a violation of human rights and an obstacle to the achievement of equality, development and peace in society.

We do not exaggerate if we say that domestic violence and crime in recent years, has "triumphed" over other types of crimes. Unfortunately, today the violence is very close to us, close to our home, within the family. Violence accompanies us as living and without feeling, uncontrollable, almost like an epidemic. People who experience violence as victims or witnesses, learn (among others) fear, to avoid violence or become equally violent as the perpetrator. Violence often turns to tragedy, in most cases "lucky" that accompanies human life like a shadow. Newspapers and general media report almost daily about this phenomenon difficult to handle and more difficult to report, as to understand the dynamics of violence is often not easy.

\section{Purpose}

The aim of this study is to explore the depth of the problem of violence and a better understanding of the experiences and the experience of women.

\section{Objectives of the study:}

- To discover what the women's perceptions of abusive behavior and in what circumstances;

- To discover the strategies that women use to avoid violence or to reduce its consequences;

- To identify the consequences of domestic violence on women;

- Identify women's attitudes towards abusers and abusive relationships;

- To define the social constraints faced by battered women; 


\section{Meaning domestic violence.}

Albanian law defines domestic violence as "any act or omission of a person to another person resulting in the violation of physical integrity, moral, psychological, sexual, social and economic, committed between persons who are or have been family relationship ". The definition of domestic violence in the sense of Article 3 of Law no. 9669, dated 18.12.2006 "On measures against domestic violence", unless specified otherwise in particular its provisions, the terms "violence" means any act or omission of a person to another person, resulting in a violation of their physical, moral, psychological, sexual, social, and economic. "Domestic violence" means any act of violence committed between persons who are or have been in a domestic relationship. In most cases directed violence, against women within the couple, from parents to children, among children themselves, parents from children to the elderly run against persons with disabilities.

Physical violence includes: delay, hitting, scratching, pinching, biting, throwing, closing at home, hitting with various objects, threatening with a knife or other weapon, refusing to help the woman when she is pregnant, or 24 target, to form the most serious - murder, attempted murder, injury, etc. Physical violence is a form of violence that victims have easier to perceive and accept the very nature of its exercise and visible traces it leaves on the victim.

Moderate physical violence - includes one or more of the following physical, collisions with kicks, jumps on, postponements, withdrawals dragging, slapping and / or hair pulling.

- severe physical violence - includes one or more of the following physical, shocks, beatings, burning with purpose, spirit or drowning seizures, and / or weapons threats or use of a weapon against a person.

- Physical violence with guns - including threats and / or attacks with guns or any other object that can cause physical injuries. Physical violence with serious injuries - including physical violence that causes physical injury to a person.

Sexual violence includes: treatment of partner (partner) as a sexual object, the obligation to striptease, forced to have sex, insisting to touch and to do everything you want, the obligation to have sex with someone else, committing acts sadistic sexual, forcing the partner to have sex after physical abuse or as a condition to maintain their relationship, extramarital sexual relations etc. It is noted that spouses or partners who practice this form of violence, want to demonstrate their strength and ability to dominate and to humiliate the victim.

Psychological violence includes ignoring the feelings of the wife, constant criticism, contrary to ongoing thoughts, humiliation in public or private, try to convince his partner that violence deserves its actions, threat partner for adultery, signs of jealousy constant threat of taking the children, keeping the money hidden, home maintenance work, child abuse, etc. calls degrading names. Most psychological abuses occur in the context of other forms of abuse including verbal, economic and social isolation. Men who exercise physical abuse, psychological abuse and usual practice. Psychological violence to its own nature, it is very difficult to identify, because it leaves visible traces, such as physical, but verbal attacks, humiliation, threats, restrictions may be even more damaging than physical assault.

Four different types of psychological violence:

- Verbal violence - when the woman criticized, insulted, humiliated and / or speak in a way that attacks the character and troubled sense of self-worth and self-confidence.

- Psychological threats - when the woman is threatened and that caused a sense of fear through threats to physically hurt him and / or others close to her, and / or to destroy something that is important to by undermining the sense of security.

- Controlling behaviors - when a woman ignored, kept under control and isolated from jealous behavior and accusing the wife is unfaithful to him shaken sense of self-worth and self-confidence.

- Economic Violence - keeping under control the money of the house, including the salary of the woman, where she is employed outside the home. Economic violence has to do with controlling partner's financial income family or a ban on participation of women in decisions on spending money, even refusing to give money to cover basic household needs, denial of ownership of property joint, damage or destruction of property, theft of property, etc. 


\section{The consequences of violence on victims can be categorized into three groups:}

Consequences related to mental health, depression, fear, anxiety, lack of self-esteem, anorexia and insomnia, posttraumatic disorders, suicide attempts.

Consequences related to physical health: death, partial physical disability or permanent injury, abuse drugs and alcohol, irritable bowel syndrome, smoking or unprotected sex devastating.

Consequences related to reproductive health, unwanted pregnancies, gynecological problems, sexually transmitted diseases, abortions, etc. underweight births.

\section{Some factors affecting domestic violence}

Despite what is said often, domestic violence is not caused by disease, gene, alcohol or drugs, loss of self-control, anger, stress, the victim's behavior or problems in the relationship / couple, but, by the desire to dominate someone for I had it in hand, to decide to exercise the power of control. So the key factors of domestic violence related with power and control that seeks to establish the man over woman, the parent on the child, others on persons with disabilities. Below we list some other factors (secondary) that may affect the domestic violence and can be classified into.

macro-level factors, including: the impact of culture, economy, politics, etc. large demographic movements.

micro level factors (family or micro), which may include family relationships, patterns which are grown, family education, upbringing of children, etc.

personal level factors, which may include: mental health problems of the individual, alcohol abuse, drugs, stress, cultural level, various personality disorders, personal experiences in family relationships, etc.

\section{Methodology}

The method chosen to carry out this study is case study that focuses on one or a few units of a particular phenomenon order depth study of events, relationships, experiences or processes that appear within this particular unit. This type of study is a very popular study in social sciences, especially in small-scale studies. The case study method focuses on a elementev units that will be studied and aims to illuminate the universal in the particular seeing.

The real value of the case study is that it provides the opportunity to explain "why-to" things that happen, rather than simply finding out what these things are. Usually the case that forms the basis of the study exist in a natural way, not an artificially created situation for the purposes of this study means that the case is a naturally occurring phenomenon appeared. Case study aims to study in depth the events, phenomena and various social situations with an emphasis on relationships / processes rather than results and final product. This type of study has as main focus of the particular study that is studying the issue and is not intended just to get a general panorama of the issue. Another feature of the study is that it uses more resources than a research method (Tahiri.F, Rama.R, Sota.M, research methods in social sciences, EEST PRINT, Tirana 2013).

\section{Sampling and methods of selection}

The group of participants consists of 3 cases of battered women who live in the northern area. The purpose of the sampling was to understand the experiences of women raped, forms of violence they experience and they found support from family and friends. This sample is not representative for battered women and their experiences. However it notes that customs and experiences that women have expressed in these interviews, can be characteristic for many Albanian women.

Selection of participants was conducted through sampling qëllimëshëm. This method operates on the principle that we can get more accurate information if we focus on a relatively small number of people and that are selected to be part of the study on the basis of recognized qualifications. Intentional sample gives us the ability to select on the basis of suitability and knowledge that the researcher who is studying the issue. Based on prior knowledge, the researcher can intentionally select the sample in order to ensure the full inclusion of people or issues in our case study.

To discover how abused women describe their personal experience, they were used qualitative research methods. For this study was designed to guide the interview that the format was based on semi-structured interviews and the interviews were conducted three meetings for each woman. For the compilation of interviews, we tried to develop questions as neutrally as 
possible, in order to discover the local interpretation of the issue. The interviews covered several topics, some of which were related to violence, while others were related to family life. Topics related to violence covered questions ranging from the creation and negotiation of conflict, the specific arguments as a result of conflict, to the violent events and their consequences for both partners. In the sphere of everyday life, the questions included the division of roles within the family, the decision-making process, the issue of joint activities within the family or individual.

The interview included a series of open questions about women's experiences in connection with the abuse. Questions were designed to elicit concrete answers were combined with open-ended questions so that respondents could describe their experience in their own words. In semi-structured interviews the interviewer is prepared to be flexible in terms of the scope in which the topics are taken into consideration and allow the interviewee to develop ideas and could speak more fully about the matter raised by the researcher.

\section{Limitations of the study.}

1. limited time to address the case in detail

2. Difficulty in finding women raped since the shelter to battered women do not get the woman voluntarily to realize an interview

3. Difficulties for conducting interviews with battered women since the two of them continue to live with the abuser.

4. Limit was the difficulty of finding a suitable place to conduct interviews

\section{Analysis results of the interviews}

The term violence against women refers to any act of violence based on gender, which has the effect or will certainly have the effect of injustice physical, sexual or psiklogjike, inflicted on women and girls, whether this violence have occurred in private or public situations. Men's violence against women in general is characterized by privacy, which means that they hold just inside the door of the house and do not expose. It is clear in this study, after three cases were initially kept secret and even counseling to the relatives had not sought. Women's narratives prove that abuse is a complex phenomenon that includes various forms ranging from isolation, forced prostitution, sex with violence and up to violence during pregnancy.

Acts of physical and psychological abuse often addressed not only the respondents but also family members.

\section{- Physical abuse}

When people talk about domestic violence, often referred to physical abuse of a spouse. Physical abuse is the use of physical force against someone in a way that injures or endangers that person. Physical abuse in situations of domestic violence includes a wide range of behaviors, including, but not limited to stroke, beating, choking, kicking, pulling hair and attack with crowbars. Physical attack or beating of a partner or a family member if a crime occurs inside the house, if it happens abroad.

There was controversy regarding the definition of physical violence. Two cases were with the 8-year education was not impressed a buffet, while the case was highly educated was serious concussion. This is related to the manner in childhood socialization random third-Besa. Various forms of physical violence that resulted in this study, which were experienced by women in their marriage are: throwing or pushing, slapping and kicking, pulling hair, lug, hitting with hard objects that can hurt.

Impacts of physical violence in its various forms to battered women can often be severe, which can lead to short or long term problems of physical health, disability, and even death caused by murder or suicide.

Psychological abuse

From interviews, three cases of psychological abuser sampling gave the following features:

There is no desire to change behavior;

Everything he does, thinks that it is right;

Do you think that woman is, the poor and to be subjected to violence; 
There has learned to take responsibility for their actions;

abuser is obsessed and compulsive, as is taught and also thinks that it will continue;

Despite can leave the impression that, in real perpetrators are not confident, so they always feel insecure;

Bullies o simmer with jealousy, hatred and bitterness. Usually they have a wide range of prejudices that cast on others;

Bullies are people who have not learned to cope with the consequences.

Some forms of bullying, issued by the interviewer:

One of the most common forms of bullying threat. Curses are a pattern of behavior used rënçëm family, especially the mother. Curses represent a human effort powerless to influence something over which he has no influence. His powerlessness he compensates with the curse, which is intended as a magical wish that the person appointed to happen a bad thing. Increase voice and swearing in the reality of today no longer pose a problem, since it seems to have turned into something very common in any environment, especially in the family. Raising one's voice becomes the goal of imposing others. While swearing, mean that the relationship between them is tense, things are not going well. Men shouting feel that there is no negative consequence, so its use does not seem a problem.

The third type of domestic violence measured in this study is sexual violence. Sexual violence includes any situation in which a woman is forced to participate in sexual activity degraded, unwanted or unsafe.

Domestic violence has profound consequences on the welfare of women in general. Exercise of domestic violence puts women at greater risk for physical and mental health including depression, anxiety, trauma, insomnia, low self-esteem, pessimism about life, injury and suicidal tendencies. These specifications continue after stopping the violence for a long time. The more severe the abuse, the more severe its impact on physical and mental health of women. The impact of the different types of abuse and of multiple episodes, it seems that are increasing over time.

Domestic violence isolates women directly and indirectly from their support network. They gradually reduce their social activities at the request of their partners, or shame or out of concern not to worried friends and family.

\section{Conclusions}

This study is a qualitative study designed to explore the perceptions, beliefs, attitudes and behaviors of women raped Albanian, consequences and ways of coping with domestic violence. The study suggests that there is a complex interweaving of cultural, social, economic and interpersonal factors that may put women at increased risk of violence Albanian. The findings dispel the myth that domestic violence is largely a problem of the poor and uneducated, and that abuse transcends socio-economic boundaries.

The interviews identified atafgjata tragedies that have imbued the lives of women, each of which shows the life killed by hidden pain, but also announced the resistance of many of them. The study shows that abuse in relationships between partners is more likely to occur and continue, when the couple, especially the man, holds traditional attitudes toward family roles. The findings indicate that abusive men are dominant in the decision making process of the family, while women are expected to assume responsibility for housework and childcare.

Even when a woman is at high level professional and social, it is not exempt from bearing the burden of all the household chores. Women need to fulfill their roles as wives and mothers, and be prepared to sacrifice their lives for the sake of marriage.

Women still have to act as prescribed by burrat.Rëfimet women have proved that domestic abuse is a complex phenomenon, and includes various forms of verbal, emotional, physical, sexual and economic. Domestic violence has profound effects upon children, whether they suffer physical violence or not. Social isolation is also mentioned as a strategy used by abusive partners to increase control and reduce the ability of women to leave abusive relationships.

It feels the need to tackle domestic violence in Albania. We have built a good relationship of cooperation between the Government and civil society to combat violence against women. In order to reduce the incidence of domestic violence in Albania, it is necessary to create a common vision that will lead us into actions. To prevent violence, but also to help the victims, lawyers, psychologists, doctors, police and social workers work together. 


\section{Recommendations}

- The training of social workers in the community how to inform the victim about legal liability, available financial support or other support provided by the state, procedures to ensure this support. They should be trained to identify violence and victims who need treatment.

- Establish programs to increase the level of education of women in order to facilitate their employment.

- Develop training on domestic violence issues for journalists and students respect the victims.

- Plan and sex education in schools and to prevent gender violence.

- Policies to promote cooperation of various stakeholders in this field, such as police forces, health workers and social workers.

- Policies to reiterate the institutional capacity to efficiently respond to the violence of women.

- Set up support groups for battered women where they have the opportunity to share their experience.

- Build community networks where coordinated and integrated health system, the judicial, police, churches, social workers and community groups meet regularly to develop and implement a coordinated response to domestic violence.

\section{Bibliografia}

[1] Unicef, Dhuna ndaj grave në familjet shqiptare

[2] INSTAT Dhuna në familje në Shqipëri Vrojtim kombëtar me bazë popullatën, 2013

[3] Avokati i Popullit. Thuaji Jo. Në emër të nënave, Në emër të bijave, Në emër të bashkshorteve, në emër të jetës. Mars 2015

[4] Mills, L. Fuqizimi transnacional i grave të dhunuara: Rasti i ndërhyrjeve post - modern, 1996

[5] Aleanca Gjinore për Zhvillim. 'Dhuna në Familje, Paraqitje e situatës aktuale në Shqipëri 2006

[6] http://www.undp.or.jp/undpandjapan/ëidfund/pdf/Albania_Manual\%20for\%20Policy\%200fficers\%20in\%20Alba nia.pdf

[7] http://www.amnestyusa.org/our-ëork/issues/ëomen-s-rights/violence-againstëomen/violence-against-womeninformation

[8] http://ëëë.amnestyusa.org/our-ëork/issues/ëomen-s-rights/violence-against-ëomen

[9] http://www.womenshealth.gov/violence-against-ëomen/types-of-violence/

[10] https://www.coe.int/t/dghl/standardsetting/equality/03themes/violenceagainstëomen/Article\%2012.pdf

[11] https://www.unodc.org/res/cld/document/criminal-code-of-the-republic-of-albania-2014 